\title{
Jesus as healer in the Gospel of Matthew: In conversation with Alan Culpepper
}

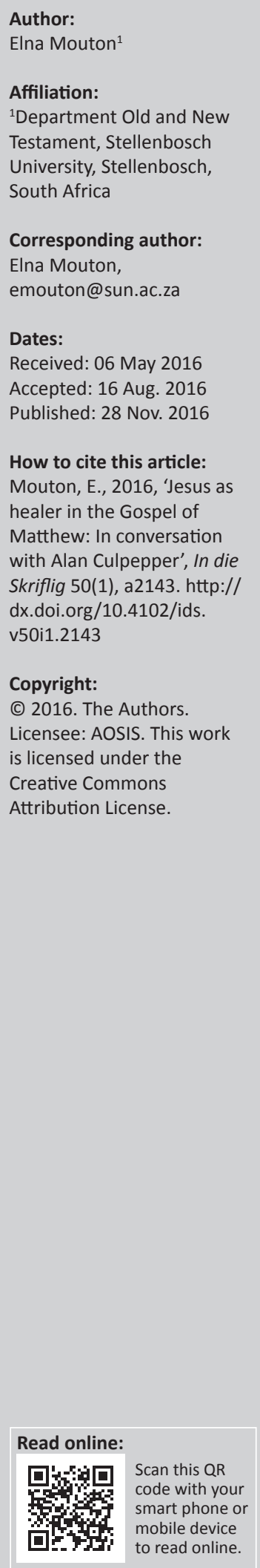

This article is a response to R. Alan Culpepper's two-part contribution in this volume, 'Jesus as healer in the Gospel of Matthew'. It focuses on three sets of implications of Culpepper's work: implications of a bioethical reading of Matthew; implications of a vulnerable, compassionate God in the midst of suffering; and implications of a comprehensive healing ministry for Christian churches today. The core of the essay is Jesus of Nazareth as paradoxical expression of God's presence amidst suffering, identifying with people in need while embodying God's encompassing renewal of creation.

\section{Introduction}

I was invited to respond to Alan Culpepper's two-part contribution in this volume, 'Jesus as healer in the Gospel of Matthew' (2016). Somewhat aware of the rich yet complex nature and (potential) implications of the topic, I hesitantly accepted the challenge.

In general Culpepper gives a cursory yet profoundly nuanced overview of Jesus' role as healer according to Matthew. I find his sophisticated, multilayered approach helpful in various ways: firstly, his artistic combination of narrative criticism, medical anthropology, ancient Mediterranean culture, and views of healing in second temple Judaism; ${ }^{1}$ and secondly, his fine exegesis of the structure, socio-cultural context, and rhetorical purpose of the healing narratives in Matthew 8-9; and thirdly, the particular God images that his analysis of Jesus as healer brings to the fore. All of this happens through his imaginative retelling of the narratives in Matthew 8-9, skillfully interwoven with comments on the socio-cultural context of the text.

In the first section of part 1, 'Jesus as healer in the light of medical anthropology', Culpepper responds to '(t)he primary difficulty we encounter in interpreting Jesus' role as healer', namely 'that the gospels make use of 1st-century Hellenistic-Jewish language and concepts that would have been common to both their writers and their first audiences'. As a crucial step towards identifying 'meaningful principles for bio-medical ethics' in the 21st century, he explores Jesus as healer in the light of medical and Mediterranean anthropology in the 1st century. These disciplines study sickness, health and medicine in diverse cultures and contexts. With reference to the influential work of John Pilch (2000), Culpepper carefully distinguishes between modern western medicine and ancient Mediterranean culture. The former primarily addresses diseases (biological and/or psychological disorders), their causes and cures, whilst the latter 'included social devaluation, loss of place, detachment, and alienation' as part of their understanding of illness, towards striving for an encompassing condition of well-being. Culpepper also refers to modern definitions that are moving towards broader definitions of sickness and health. ${ }^{2}$

In a subsequent section of part 1, 'Jesus as healer in Matthew', Culpepper discusses a second methodological difficulty that 21st century scholars encounter in interpreting Jesus' role as healer, namely:

1.The traditional view of the latter was 'that God sent illnesses as punishment for sin. Therefore, one should repent and pray for healing' (Culpepper 2016 Part 1: introductory section).

2.Culpepper (2016a: footnote 2) inter alia refers to the World Health Organisation's definition of health that has not been amended since 1948: 'Health is a state of complete physical, mental and social well-being and not merely the absence of disease or infirmity'.

Note: I gratefully dedicate this essay to the memory of a life-long friend, Willemien Appel (1926-2016), whose life and death are bold witnesses to the reality of God's compassion and care amidst suffering and injustice, particularly towards women and children. 
the nature of the gospel accounts in general and the Gospel of Matthew in particular. The gospels not only arise out of their time and culture, they record Jesus' work as a healer in the interest of announcing his identity as the Messiah of Israel and the Son of God. ${ }^{3}$

In order to read the healing stories in Matthew 8-9 with an interest in what they may offer in terms of bio-medical ethics, his reading is guided methodologically by narrative criticism (focusing on major themes in Matthew) and attention to the Gospel's implied ethos and ethics.

In the first section of part 2, 'Reading the healing stories in their literary context', Culpepper highlights explicit virtues introduced in the healing narratives of Matthew 8-9, foregrounding compassion and mercy as 'primary impulses for Jesus' healing ministry'. He then discusses the location and structure of this collection of stories. Jesus heals persons from different social groups and with various illnesses. The list of illnesses referred to in Matthew 11:4-5 approximates those named in Isaiah 26:19, 29:18, 35:5-6 and 61:1 (cf. the echo of Is 53:4 in Mt 8:17; Nolland 2005:30-31, 361-362, 451). The reference to Isaiah 61:1, 'he has sent me to bring good news to the poor', also serves as the keynote of Jesus' ministry in the Gospel of Luke (4:18). Culpepper concludes this section by saying, 'Jesus' healing ministry ... demonstrates the fulfilment of scripture, the breaking down of boundaries, his power over evil, and the restoration of persons to wholeness (shalom) and community'. With reference inter alia to Ulrich Luz and Elaine Wainwright, Culpepper emphasises that Matthew's focus is on salvation as an encompassing state of physical, spiritual and social well-being, with integration into family and community life, rather than merely focusing on the cure of certain ailments.

Towards the end of both parts of the essay, Culpepper deliberates on important implications (from the critical angles he investigated in the previous sections) of Jesus' healings in Matthew 8-9 for modern-day bioethics, appropriating Jesus' distinctive ethos according to Matthew for today's often fragmented and partial perspectives on suffering. He concludes by stating that a culturally-informed interpretation of Matthew's healing narratives may promote a broader understanding of healing, 'which might lead to greater collaboration between healthcare professionals, counselors, and ministers'.

I can only respond with very broad strokes, and would like to do so by focusing on three sets of implications from the essay, in view of the conference theme within which this discussion originally occurred, New Testament and bioethics: implications of a bioethical reading of Matthew; implications of a vulnerable, compassionate God in the midst of suffering; and

\footnotetext{
3.Matthean scholars would generally share Culpepper's perspective on this point (c. Hagner 1993:195-196; Kingsbury 1988:72-76; Levine 2012:470-471; Nolland 2005:344-346), particularly regarding Matthew's reworking in chapters 8-9 of material paralleled in Mark and Luke (cf. France 2007:300; Patte 1987:109-135; 'These two chapters have ... been designed to play a foundational role in the building up of Matthew's account of Jesus as the Messiah'). Confidence in Jesus' identity and authority ( $\dot{\varepsilon} \xi \circ 0 v \sigma i \alpha)$ would prepare his disciples for being sent out by the same authority (Mt 4:23; 9:35-10:4; cf. Nolland 2005:408-411).
}

implications of a comprehensive healing ministry for Christian churches today. ${ }^{4}$

\section{On reading Matthew (bio)ethically}

A first set of implications from Culpepper's work concerns the biblical text at hand.

An ethical reading of Matthew's Gospel may refer to a wide range of issues. Since Elisabeth Schüssler Fiorenza's presidential address at the Society of Biblical Literature in 1987 (Schüssler Fiorenza 1999:17-30; cf. Mouton 2002:21-25), the so-called 'ethics of interpretation' has become an important challenge to present-day readers and audiences of the Bible to be accountable for their acts of reading and hearing - both with regard to the dynamic nature of the literature involved as well as the socio-historical contexts within which it is received.

A bioethical reading of Matthew's Gospel involves an exploration of Jesus' healing narratives from the perspective of ancient Jewish, Mediterranean, Hellenistic and Roman cultures, as well as modern medical anthropology. That this is by no means a straightforward issue speaks from the wide variety of ways in which healing stories in the Bible in general, and the New Testament in particular, have been appropriated during the history of its interpretation (cf. Mouton 2002:201-220; 2006:52-54).

In my view Culpepper's bioethical reading of Matthew 8-9 concerns three closely related yet distinguishable aspects:

- an ethics of accountable, multidimensional interpretation of Matthew as ancient canonised text, accounting for its linguistic-literary, socio-cultural and theological-rhetorical contexts;

- and, as a logical expression thereof, its intended (bio) ethical, pragmatic or rhetorical effects;

- and its functioning and appropriation in contemporary Christian bioethos and -ethics.

Culpepper's essay reiterates Matthew's challenge to present-day readers to respect its nature and purpose as a product of its time - compiled for a specific (1st-century Mediterranean) audience, as a response to specific needs, and with specific rhetorical effects in mind. This implies that being aware of, and acknowledging the socio-cultural and rhetorical contexts and particular perspectives of Matthew's Gospel, would be as important as being aware of our own presuppositions and interpretive frameworks when receiving this ancient text today. In fact, allowing different perspectives across spatial, temporal and social contexts to interact, imagining ourselves in the dynamic world of Matthew's Gospel, asking what it was supposed to do to its first audience (Schüssler Fiorenza 1999:26-30), may provide important keys towards reappropriating it today.

4.The original context was a day conference with colleagues in the fields of New Testament and Ethics from Radboud (Nijmegen), North-West and Stellenbosch Testament and Ethics from Radboud (Nijmegen), North-West and Stellenbosch
Universities, held at the Faculty of Theology in Stellenbosch on 26 August 2015, with Professor R. Alan Culpepper as guest presenter. 
Even though Culpepper's approach is not entirely novel, ${ }^{5}$ his essay is a timely and fresh reminder of Matthew's rather unique angle on Jesus' comprehensive ministry of salvation against the backdrop of ancient Mediterranean culture. Of particular interest for Culpepper is how Matthew (8-9) portrays Jesus' identity as the Christ (Messiah) and Son of God through his embodiment of the primary virtues of

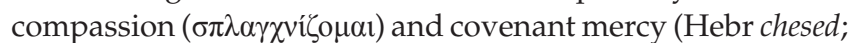
cf. 4:23-24, 9:13, 35-36). Through the healing narratives of Jesus, Matthew's Gospel witnesses to incidents where people experienced God's liberating presence in a variety of circumstances, and to how they made sense of and interpreted those experiences in terms of the symbolic worlds, language and traditions available to them.

From here Culpepper (2016a; 2016b) describes, with reference to Richard Burridge and Dale Allison, Matthew's implied ethos as a 'mimetic ethic', inviting his audience to learn from Jesus and to imitate both his words and deeds of compassion. Present-day readers of Matthew - far removed from those initial experiences in terms of time, culture, and space - are invited to do likewise, not necessarily the same. In this sense, Culpepper's conclusion on the implied ethos of Jesus' healings is particularly helpful in accounting for the dynamics of Matthew $8-9$ in view of its multilayered socio-cultural and religious-historical background, and is as such to be welcomed as a profound contribution to the current discussion among New Testament scholars and Bioethicists on sickness and healing.

\section{A vulnerable God in the midst of suffering?}

A second set of implications from Culpepper's work concerns God images, with metaphorical language for God in view of suffering, according to Matthew's Gospel.

In general, the New Testament is acutely aware of multiple expressions of (physical, mental, social and economic) suffering, of unjust behaviour and exploitative systems, of death and dying, as well as their disruptive, often devastating effects on the lives of people. ${ }^{6}$ As a radical response to the human condition of vulnerability and alienation, the concept of shalom in the Hebrew scriptures (well-being and wholeness in terms of people's relation with God, others, themselves and creation) is translated by New Testament authors with

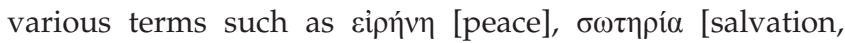

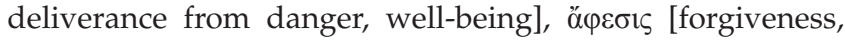

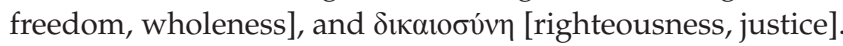

5.Cf. Hagner 1993:196-261; Malina and Neyrey 1988:xi-xvii; Malina and Rohrbaugh 1992:69-85; Nolland 2005:347-408; Pilch 2000:19-36, 75-86; Turne 2008:227-263; and especially France 2007:302-369 and Levine 2012:470-471.

6.Carter (2006:1) describes the imperial context of the first-century Mediterranean world as follows: 'The Roman Empire provides the ever-present political, economic, societal, and religious framework and context for the New Testament's claims, language, structures, personnel, and scenes'. The empire was deeply hierarchical in nature, and a small elite of 2-3 per cent ruling the population (Carter 2006:3-13). nome and its elite (male) allies in the rupire's provinces actively promoted the Rome and its elite (male) allies in the empire's provinces actively promoted the claims that Rome and its emperor were agents of the gods' rule, manifesting the gods' blessings (security, peace, justice, faithfulness, fertility) among those that submit to Rome's rule. These theological claims justified efforts to force people into submission to the empire's hierarchical structures and self-enriching ethos (2006:83-85). The early followers of Jesus would have been confronted with these claims on a daily basis.
These are all-encompassing terms characteristic of life in God's new kingdom (empire), referring to reconciliation, liberation and healing related to physical health, peace of mind, human relations, social justice, peace with God, and ecological well-being. Jesus' entire ministry has to be appreciated within this radical and all-inclusive manifestation of God's kingdom in the world. His healings and exorcisms were in fact signs of a paradigmatic shift in the power controlling people's lives and fate on earth.

According to Matthew's Gospel, Jesus' first public speech is the proclamation of the good news that God's kingdom has come near (Mt 4:17; cf. Mk 1:15; Lk 4:43). In the previous and ensuing chapters the encompassing nature of this kingdom unfolds dramatically through Jesus' birth narratives, his authoritative teachings and parables, his miraculous healing of people challenged by various illnesses, his forgiveness of sins, ${ }^{7}$ and his control over natural elements. ${ }^{8}$ Jesus is often described as being among the sick and needy, as having compassion for them and curing them (Mt 4:23-25; 9:35-36; 14:14; cf. Mk 2:10; 3:7-12; Lk 6:17-19). People cried out to him for help (Mt 20:29; cf. Mk 10:47), even though the crowds and Jesus' own disciples were inclined to rebuke and silence them (Mt 20:29, 31; cf. Mk 10:13, 48; Lk 18:38-39). Jesus' response, on the contrary, was that of seeing distressed people, stopping by the roadside, acknowledging their humanity and need, having compassion for them, and touching them - more often than not against society's cultural and political grain $(\mathrm{Mt}$ 8:1-9:38; 20:32-34; cf. Mk 10:16, 49-52; Lk 18:40-43; Culpepper 2016b, part 2). ${ }^{9}$

Even though the synoptics often report that people were overwhelmed with amazement at what they experienced, that the authority of Jesus' words and deeds caught them by surprise (cf. Mt 9:33; Kingsbury 1988:125-126; Turner 2008:226), it was hard for both Jews and Greco-Romans to understand that all of this would be enabled by a suffering messiah who laid down his life for people. Though crucifixion was a fairly routine matter in the Roman Empire at the time, resurrection was not - certainly not the resurrection of a crucified messiah. When John the

7.It is important to note that the synoptic tradition does not treat physical healing in isolation from the forgiveness of sins and other expressions of well-being (cf. Lk $5: 17-26)$

8.Matthew shows how - through Jesus' life, death and resurrection - God's sovereignty over every power is asserted, ultimately over Rome's power and death (Carter 2006:92-98; 2010). Jesus' followers understood him to be lord, the lifeCaving $2006: 92-98 ;$; giving $\kappa \cup p 10 \varsigma-$ not the emperor, nor Jupiter. For them, Jesus manifested the empire

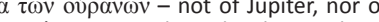
Rome (Carter 2006:85, Nt 4:17, 8). 'All of Jesus' actions and words - his teaching healings, feedings, meals, exorcisms, conflicts - manifest God's saving presence' (Carter 2006:95).

9.In contrast to the hierarchical structures of 1st-century societies under Roman imperial rule (cf. Carter 2006:3-13), dominant values of honour and shame, and the aspirations of his own disciples to be in positions of power, Jesus proclaims that $\mathrm{He}$ 'came not to be served but to serve, and to give his life a ransom for many' (Mk 10:45; cf. 9:33-35; 10:35-45 NRSV). Paradoxical narratives of a compassionate, suffering, crucified, wounded, traumatised yet liberating, healing Messiah would inspire theologians to (re)name God - inter alia in terms of God's vulnerability (Placher 1994:87-108: Reynolds 2008:159-168), humility, kenosis, cruciformity (Gorman 2001), and disability (Eiesland 1994:89-105). For them these characteristics represent God's very nature and identity, revealed in Jem these characteristics represent God's very nature and identity, revealed in Jesus for the advantage, edification, and welfare of others. With reference to Philippians 2:6-8 (where Christ is described as status-renouncing, self-giving and others-regarding) Gorman argues (2001:268-302) that kenosis and humility would not be associate with deity in that context. Ironically, this 'weakness' according to Greco-Roman moral standards, becomes the liberating and healing power of God for Paul and the synoptics. 
Baptist, for instance enquired from prison about Jesus' identity ('Are you the one who is to come?'), Jesus responded by reminding him of the signs of God's kingdom, yet also by warning him not to be offended by the strange, paradoxical ways through which this kingdom would come on earth:

The blind receive their sight, the lame walk, the lepers are cleansed, the deaf hear, the dead are raised, and the poor have good news brought to them. And blessed is anyone who takes no offense at me. (Mt 11:4-6; cf. Lk 7:22-23) ${ }^{10}$

Culpepper's essay remarkably shows how God's concern for humanity is revealed in and through Jesus of Nazareth. In fact, Jesus' incarnation and entire earthly ministry may be described as a response to the trauma and suffering of creation. ${ }^{11}$ As such his mission may be phrased as the lifegiving, community-creating, hope-sustaining work of a pregnant, mothering messiah. Images of a compassionate, caring, vulnerable God in solidarity with creation, identifying with illness in and through Jesus, offered radical perspectives on the many faces of human suffering in the 1st-century Mediterranean world, and through the course of history, in many different contexts. These images have the potential to continue to do so in even more profound ways as our understanding of ancient medical anthropology and folklore grows (Culpepper 2016a).

In the final analysis, Culpepper suggests that 'our role as readers is to play the role of the implied reader, enter into the narrative world of the Gospel, and hear the narrator's story about Jesus as fully as possible' (Culpepper 2016a; cf. Iser 1974)..$^{12}$ This means that present-day readers and audiences of Matthew have to choose faith-fully to give priority to God's compassionate presence and healing power over and amidst

10.The synoptic Gospels describe the kingdom life in relation to God as a life of discipleship and loyalty to Jesus (Mk 8-10), a life of righteousness (Mt 5-7), of freedom and wholeness (Lk 4:18-21). Luke, for instance retells the narrative of Je was in a socio-politicalcontext probably after the Jewish-Roman war of 66-70 ce. It was a devastating time economically and religiously, which would pose great challenges to how the followers of Jesus imagined and embodied the memory of their crucified, risen Lord. The story unfolds according to the programme that Jesus announced in Nazareth (Lk 4:16-21), introduced by 'The Spirit of the Lord is upon me'. Accordingly, his earthly ministry would focus on his encompassing power to heal, to forgive sins and to release all kinds of captives (such as poor and socially disowned people, the sick and demon-possessed, strangers and outsiders). The Greek noun ö $\varphi \varepsilon \sigma 1 \zeta$ ('acquittal of debt' or 'release from prison') is the most common metaphor Luke uses for the forgiveness of sins, the upliftment of the weak and the healing of illness. The essence of Jesus' ministry, according to Luke, is to set people free (Bosch 1989:5-18. 1993:16, 30). Significant of these life(1) restoring images in the synoptic Gospels about God in relation to creation, is that (Mt 10:1, 6-8; 25:34-40; Mk 3:13-15; Lk 6:12-19; cf. Culpepper's reference to Matthew's 'mimetic ethic' - 2016a).

11.For the Early Church, the Christ event would fulfil, amplify and reconfigure all previous experiences and interpretations of the God of the Jewish scriptures (cf. Culpepper 2016b: in 'Reading the healing stories in Matthew 8-9 for their implied ethics'). Mouton (2006) states: In Jesus of Nazareth, God is found in places where God would not be perceived. In Jesus, God is dramatically present at the margins of human existence. In showing compassion to children, tax-collectors, Samaritans, and women, Jesus subverts the established values of power in the moral world of 1 st century Palestine. He dies violently at a place where criminals were executed. Through the trauma, humiliation and shame of Jesus' death on a cross, a shocking vision of God is presented. The ultimate site where God would not be perceived, paradoxically is premes the site of God's presence. In this way God's concrete presence in Jesus becomes a radical moment of surprise, inviting people to look differently. (p. 57, fn. 6)

12.Cf. the repetition of óṕ⿴ in Matthew 8-9, and particularly the unusually high concentration of Matthew's characteristic ídov̀ as attention marker in 8:2, 24, 29, $34 ; 9: 2,3,20,32$ Nolland (2005:348-349). the fragile and broken realities of our earthly existence (1:23; $18: 20 ; 28: 18-20) .^{13}$

\section{Living boldly with paradox and risk}

A third set of implications from Culpepper's essay has to do with the transformative potential of Matthew's Gospel for Christian ministries of healing today. It lies specifically in Matthew's ability to reorient his (later) readers and audiences in accordance with the radical example of Jesus as encompassing healer and saviour.

The suffering of humankind and creation has become such a dire issue in the 21st century that we can rightly speak of an age of trauma. Apart from the atrocities of violence and war and the persistence of poverty, famine and disease that constantly plague the well-being of humanity worldwide, the earth suffers deeply from all forms of exploitation, discrimination and abuse. Christian communities are challenged inter alia to 'reconcile' God's creative power and caring love with phenomena of suffering and evil in the world (the so-called theodicy problem). Closely related to these are questions on the relation between suffering and sin, faith and healing, faith and culture, faith healing and medical treatment, faith and euthanasia, et cetera.

Culpepper convincingly showed how Jesus reversed, reordered and upset the familiar, conventional preconceptions of God and humanity by consistently practising an ethos of compassion and mercy. However, Matthew does not offer God's empathy and compassion for creation as cheap consolation for the complex mystery of suffering in the world. In continuation with Jesus' comprehensive ministry of liberation and healing, Matthew views human beings as having been set free and made whole in relation to their physical, socio-cultural, religious and ecological realities.

While these visions describe quality life in God's kingdom, suffering and death, however, persist as a mysterious reality in the interim. While the life, death and resurrection of God's Messiah opened up new possibilities for humanity and the rest of creation, they still have to wait with eager longing and yearning for the fulfilment of God's promises in order to be set free from their bondage to injustice, marginalisation, futility, mortality and decay. Matthew therefore invites present-day readers to reinterpret boldly Jesus' ethos and continuing presence, while living patiently and humbly with the tension of risk, paradox and ambiguity - even of ridicule and pain as they lament and resist violence, poverty and injustice. In this regard, it would have enhanced Culpepper's bioethical reading of Matthew to have included (more) feminist and postcolonial voices.

13.The canonical context within which the Gospel of Matthew occurs, is the multivocal witness of the New Testament writings to God's dramatic, cosmic victory over illness and death through the resurrection of the crucified Messiah. At the same time the New Testament looks forward to a dispensation in the future where God's creation will be liberated completely from the effects of death and dying, from creation will be liberated completely from the effects of death and dying, from corruption and mortality, from social and structural injustice, and where every
and everything will be made new according to God's saving grace in Jesus. 
Following Matthew's Jesus in health professions today - be it medical, legal or social - would mean asking ourselves what the impartial, unconditional compassion and mercy of Jesus would require from us in decision-making processes and the carrying out of our daily responsibilities. Even though the pre-scientific symbolic world of the New Testament may differ radically from our (post)modern individualistic (often apathetic) thinking, first and later Christian believers live by the same fundamental identity as followers of Jesus. ${ }^{14}$

If - as Culpepper (2016b in 'Reading the healing stories in Matthew 8-9 for their implied ethics') rightly argues - the goal of healing in the New Testament world was 'the full restoration of a person to a state of wellbeing and their place in their family and community', there is a dire need for Matthew's Gospel to be interpreted imaginatively and creatively today. ${ }^{15}$ To view human beings in relation to their emotional, physical, social, religious and ecological environment would be in continuation with Jesus' encompassing ministry of healing. In this sense, congregations (and their representatives in healing professions) are called to be 'healing communities' - a concept that grew in popularity during the past decades (cf. Bosch 1993:32-36).

In my view, the threefold set of implications of Culpepper's bioethical reading of Matthew's Gospel, discussed above, would challenge churches across the globe at least to acknowledge an interrelated thrust of perspectives on the nature and purpose of a ministry of Christian healing:

- A ministry of Christian healing would, according to its core identity, be characterised by the impartial, unconditional love and compassion of God in Jesus Christ - expressed through words and deeds of humble yet powerful service and care.

- A ministry of Christian healing would be challenged to work towards a vision of health and healing as encompassing concepts, involving human beings in all their relations to God, themselves, society, and creation.

- A ministry of Christian healing would be challenged to remember backward and forward - living from the memory that God removed the sting of death through the cross and resurrection of Jesus Christ while reckoning with God's promises of a new heaven and earth which are yet to be fulfilled. Meanwhile, Christian healers are encouraged to be 'living reminders' (Nouwen 1977) of Christ's compassion and resurrection power (cf. Mt 28:18-20).

14.A modern medical practitioner or traditional healer can, for instance not be compared simply and mechanically to a healer in New Testament times. As it is, modern hospitals owe their existence to the ministry of the Early Church and monasteries as expressions of Jesus' encompassing salvation (Bosch 1993:33). A significant shift occurred during the Middle Ages, however, when the ministry of healing gradually became isolated from the rest of the church's ministry. Moreover, during the European Enlightenment the human body was increasingly treated as an object isolated from the encompassing biblical concept of shalom (Bosch 1989:18-20: 1993:33). Peace with God was now regarded as separate from socia justice, healthy human relations and physical well-being. To 'heal' simply meant justice, healthy human relations and physical well-being. To 'heal' simply mean focused more on physical well-being and the church on so-called 'spiritual' wellfocused more on physical
being and peace-making.

15.Cf. Lategan (2016a; 2016b) for a sound discussion of these terms, as well as examples of social transformation (from South African contexts) substantiated by accountable hermeneutics.
Reading Matthew's Gospel today would thus require from Christian churches the rare gift of listening with discernment - with respect to the text in its rich yet complex multifacetedness, to its God images, and to the many contexts where it is received as a sense-making and hope-sustaining document (cf. the Shema in Dt 6:4, foundational to Jewish covenantal thinking, and affirmed by Jesus as 'the greatest command' - Mt 22:37). A hermeneutic of listening implies the willingness to hear with openness and receptivity. It includes paying attention to, acknowledging, submitting to the paradoxical, lifegiving authority of God's words in human language. It reclaims the transformative potential of an ancient writing such as Matthew's Gospel as an invitation to accomplish a healed and healing body of Christ, characterised by a radical ethos of compassion and care. Ultimately, a hermeneutic of listening gives priority to the imaginative possibilities of God's compassion over the vulnerable realities of our lives and the world.

\section{Acknowledgements}

\section{Competing interests}

The author declares that she has no financial or personal relationships which may have inappropriately influenced her in writing this article.

\section{References}

Bosch, D.J., 1989, 'Mission in Jesus' way: A perspective from Luke's Gospel', Missionalia $17(1), 3-21$

Bosch, D.J., 1993, Good news for the poor ... and the rich, CB Powell Bible Centre, Pretoria.

Carter, W., 2006, The Roman empire and the New Testament: An essential guide, Abingdon, Nashville.

Carter, W., 2010, 'Jesus' healing stories: Imperial critique and eschatological anticipations in Matthew's Gospel', Currents in Theology and Mission 37(6), 488-496.

Culpepper, R.A., 2016a, 'Jesus as healer in the Gospel of Matthew', part 1, 'Methodology', In Luce Verbi, 50(1).

Culpepper, R.A., 2016b, 'Jesus as healer in the Gospel of Matthew', part 2, 'Jesus as healer in Matthew 8-9', In Luce Verbi 50(1).

Eiesland, N.L., 1994, The disabled God: Toward a liberatory theology of disability, Abingdon, Nashville.

France, R.T., 2007, The Gospel of Matthew, Eerdmans, Grand Rapids.

Gorman, M.J., 2001, Cruciformity: Paul's narrative spirituality of the cross, Eerdmans, Grand Rapids.

Hagner, D.A., 1993, Matthew 1-13, Word, Dallas.

Iser, W., 1974, The implied reader: Patterns of communication in prose fiction from Bunyan to Beckett, Johns Hopkins University Press, Baltimore.

Kingsbury, J.D., 1988, Matthew as story, 2nd rev. edn, Fortress, Philadelphia.

Lategan, B.J., 2016a, 'Some implications of the family concept in New Testament texts', in D.J. Smit (ed.), Hermeneutics and social transformation: A selection from the essays of Bernard Lategan, pp. 159-168, Sun Media, Stellenbosch.

Lategan, B.J., 2016b, 'Imagination and transformation', in D.J. Smit (ed.), Hermeneutics and social transformation: A selection from the essays of Bernard Lategan, pp. 169-187, Sun Media, Stellenbosch.

Levine, A-J., 2012, 'Matthew,' in C.A. Newsom, S.H. Ringe \& J.E. Lapsley (eds.), Women's Bible commentary, rev. edn., pp. 465-477, Westminster John Knox, Louisville.

Malina, B.J. \& Neyrey, J.H., 1988, Calling Jesus names: The social value of labels in Matthew, Polebridge, Sonoma.

Malina, B.J. \& Rohrbaugh, R.L., 1992, Social-Science commentary on the Synoptic Gospels, Fortress, Minneapolis.

Mouton, E., 2002, Reading a New Testament document ethically, SBL, Atlanta.

Mouton, E., 2006, 'The pathos of New Testament studies', Theologia Viatorum 30(1), 50-86. 
Nolland, J., 2005, The Gospel of Matthew, erdmans, Grand Rapids.

Nouwen, H.J.M., 1977, The living reminder: Service and prayer in memory of Jesus Christ, Harper, San Francisco.

Patte, D., 1987, The Gospel according to Matthew: A structural commentary on Matthew's faith, Fortress, Philadelphia.

Pilch, J.J., 2000, Healing in the New Testament: Insights from medical and Mediterranean anthropology, Fortress, Minneapolis.
Placher, W.C., 1994, Narratives of a vulnerable God: Christ, theology, and Scripture, Westminster John Knox, Louisville.

Reynolds, T.E., 2008, Vulnerable communion: A theology of disability and hospitality, Brazos, Grand Rapids.

Schüssler Fiorenza, E., 1999, Rhetoric and ethic: The politics of biblical studies, Fortress, Minneapolis.

Turner, D.L., 2008, Matthew, Baker Academic, Grand Rapids. 